162 Наукові записки ХНПУ ім. Г.С. Сковороди. Літературознавство, 2019, вип. 3(93)

УДК 821. 091

Т. Разуменко

\title{
ИСПАНСКАЯ ТЕМА В РАССКАЗАХ Э. ХЕМИНГУЭЯ «ПОБЕДИТЕЛЬ НЕ ПОЛУЧАЕТ НИЧЕГО»
}

Эрнест Хемингуэй - знаковая фигура в литературе ХХ столетия, его имя и творчество навсегда вошли в историю мировой литературы. Создание художественного мира в его произведениях неразрывно связано не только с отражением в нем действительности в различных ее ракурсах: исторической эпохи, событий, явлений внешнего мира и т.П., но и с созданием наделенных личностным началом и индивидуальными чертами образов, в первую очередь, образовперсонажей. «Через индивидуальные черты героя автор стремится выявить и черты, свойственные определенной социальной среде, профессии, категории населения и т. п.», утверждает Л. Волкова $[1$, c. 95]. Мы исходим из понимания, что Э. Хемингуэй не всегда прямо описывает черты внешнего облика, они вводятся в текст опосредованно - через впечатление, которое герой производит на окружающих, через его поступки и поведение, диалоги и монологи.

Актуальность статьи вызвана необходимостью рассмотрения через внешние проявления создания внутреннего начала хемингуэевских персонажей, их портрета и их внутреннего состояния в его рассказах, которое было характерно для периода войны в Испании. Тема жизни во время войны, обыденной реальности, крушение идеалов, недоверие к пафосным словам пронизывает его рассказы. Эти темы перекликаются со многими жизненными ситуациями и сегодня.

Творчеству Э. Хемингуэя посвящено немало работ, однако они анализируют в основном его популярные, известные, программные произведения. Лишь некоторые недавние работы касаются проблематики его рассказов: Б. Гиленсон в цикле очерков о нобелевских лауреатах анализирует жизненный путь писателя, прошедшего пять войн, говорит об автобиографичности его произведений [2].

(C) T. Разуменко, 2019

https://doi.org/10.34142/2312-1076.2019.3.93.13 
Н. Клевалина сопоставляет творчество и гражданскую позицию Э. Хемингуэя [3]. Тем не менее, тема раскрытия внутреннего мира героев испанской войны, взаимодействие внутреннего эмоционального состояния и его внешнего проявления [4] в рассказах писателя не была предметом специального исследования.

Целью нашей статьи является характеристика способа раскрытия внутреннего мира и эмоционального состояния героев, психологизм «потерянного поколения» во взаимодействии внешнего и внутреннего его проявления через гражданскую войну в Испании.

Как признается сам Э. Хемингуэй (в предисловии к пьесе «Пятая колонна»), в книге «Победитель не получает ничего» он отдавал предпочтение рассказам: «Там, где чисто, светло», рассказ под названием «Свет мира», который, кроме меня, никогда никому не нравился», «Какими вы не будете», «Недолгое счастье Фрэнсиса Макомбера», «Снега Килиманджаро», «В чужой стране», «Белые слоны» [7, с. 23].

Исследователь Б. Гиленсон в послесловии к сборнику прозы Э. Хемингуэя (1993) писал: «Как творческая индивидуальность, он сродни Байрону, Джеку Лондону, Джону Риду, Сент-Экзюпери, за ним прочно утвердилось: Байрон XX века. Прежде всего, это художник-гуманист, антимилитарист и антифашист, противник всех форм тоталитаризма, это человек принципов, внутренне независимый. Он никому не угождал и не льстил, не гнался за дешевым успехом, смело высказывал любые свои мысли. Еще к исходу 20-х годов прошлого века он окончательно определился с главной темой своего творчества: человек в экстремальных обстоятельствах, среди потрясений $\mathrm{XX}$ века» [2].

Гражданская война в Испании оставила неизгладимое место в творчестве Э. Хемингуэя. Тема «красного десятилетия» оказалась «моментом истины», он пять раз приезжал в Испанию, и, по мнению Б. Гиленсон, «понял происходящее много лучше большинства своих коллег» [2]. «Испания была местом действия первого романа Э. Хемингуэя - “Фиеста”», пишет Н. Клевалина [3]. 
164 Наукові записки ХНПУ ім. Г.С. Сковороди. Літературознавство, 2019, вип. 3(93)

Отрезвевший от первых тяжелых ранений (бессонница и ночные страхи после военных психических потрясений), Э. Хемингуэй понял, что война - испытание не для слабонервных. «Гражданская война в Испании оказалась переломным моментом в его политическом мышлении и в творческих решениях», пишет в комментарии и примечаниях Б. Грибанов [9, с. 10].

Тематика, идеи, творческие поиски Э. Хемингуэя связаны с проблемой «потерянного поколения» - участников боевых сражений 1914-1918 годов. «Кровавый отсвет первой мировой войны, через которое прошло это поколение, окружающая действительность воспринималась писателем мозаикой больших и маленьких человеческих трагедий, в которых воплощалась бесплодная погоня человека за счастьем, одиночество среди людей, безнадежный поиск нравственного идеала», подчеркивает Б. Грибанов [9, с. 8].

В романе «Прощай, оружие» запечатлена первая мировая война, в которой сражаются лейтенант итальянских войск, американец Генри и англичанка Кэтрин, и, как песчинки, унесенные ветром, захваченные кровавым смерчем войны, погибают в этом смертельном водовороте. Именно в романе воспроизведен сам процесс рождения «потерянного» человека. Фредерик Генри говорит о том, что «когда люди столько мужества приносят в этот мир, мир должен убить их, чтобы сломить, и поэтому он их и убивает. Мир ломает каждого, и многие потом только крепче на изломе. Но тех, кто не хочет сломиться, он убивает. Он убивает самых добрых, и самых нежных, и самых храбрых без разбора. А если ты ни то, ни другое, ни третье, можешь быть уверен, что и тебя убьют, только без особой спешки» $[5$, с. 708].

От военной травмы самого Э. Хемингуэя и героев его произведений берет начало обостренное наслаждение жизнью, вином и любовью, простым человеческим счастьем, покоем и радостью бытия фронтовика, перед тем, как ему вернуться в окопы, под обстрелы, в огонь войны. Что такое война в понимании большинства простых людей? «Война» - это разъединение людей, их вражда, трагическое противостояние, однако это и необходимость, когда речь идет о 
защите своей земли, отечества. Мир неустойчив, непрочен, исполнен тревоги, люди воспринимают войну по-разному, если она не касается их лично. Напомним диалог главной героини пьесы «Пятая колонна» Дороти Бриджес и горничной отеля «Флорида» Петры, маленькой старушки лет шестидесяти. Многое в восприятии испанской жизни может не сходиться с тем самоощущением, которое есть у самих испанцев, воевавших за свободу своей Республики.

Сложные чувства оставляют в нашей душе диалог Дороти и Петры, его несхожесть в реальной мирной жизненной ситуации, эти банальные вопросы и односложные ответы: «Дороти. Яиц нет, Петра? Петра. Нет, сеньорита. Вы уже завтракали, Петра? Нет, сеньорита. Принесите себе чашку и выпейте со мной кофе. Ну, скорей. Я выпью после вас, сеньорита. Очень было здесь страшно вчера во время обстрела? Вчера? Вчера было чудесно. Сеньорита, что вы говорите? Ну, право же, Петра, было чудесно. Петра. На улице Прогрессо, там, где я живу, в одной квартире убило шестерых. Утром их выносили. И во всей улице не осталось ни одного целого стекла. Теперь так и зимовать, без стекол. А здесь у нас никого не убило» $[7$, c. 41$]$.

В сочетании изображения внешнего облика и внутреннего, психологического своеобразия человека возникает большая доля подчеркнутой эмоциональной контрастности: «Филипп - репортер, газетчик... ведет жизнь мадридского шалопая, он много пьет» [7, c. 43]; у местного убитого жителя «носки... были такие грязные, и башмаки стоптаны до дыр, и рубашки совсем не было» [7, с. 44]. Здесь нет прямого авторского высказывания, но об отношении писателя к происходящим событиям свидетельствует четкая расстановка социальных аспектов.

Известный литературовед Ю. Лотман акцентирует внимание на том, что проявляющиеся черты людей определенной эпохи, психологические отличия женского и мужского поведения, социальные трагедии, различные варианты воплощения самого понятия «человек» помогают раскрыть внутреннее состояние персонажей [10]. В рассказе «Там, где чисто, светло» появляется чувство 
166 Наукові записки ХНПУ ім. Г.С. Сковороди. Літературознавство, 2019, вип. 3(93)

безнадежности жизни. В рассказе, на наш взгляд, проходят две темы: одна, выраженная преимущественно в воспоминаниях, диалогах, вторая - в отношении к ним окружающих. Главный герой рассказа - просто Старик (без имени): «Оба официанта в кафе знали, что старик подвыпил, и хоть он и хороший гость, но они знали, что если он слишком много выпьет, то уйдет, не заплатив; потому они и следили за ним», а старику просто «нравилось сидеть в кафе допоздна, потому что он был глух, а по ночам было тихо, и он это ясно чувствовал» [5, с. 280].

Стареющий, больной человек, «ему, должно быть, лет восемьдесят», скорее всего он участник первой мировой войны, оглохший от ранения, может быть контуженый, многое испытавший, во многом разочаровавшийся, он одинок среди людей, каждую ночь он пьян, и каждую ночь его может забрать патруль. «Противные эти старики», «Лучше бы он помер на прошлой неделе», - цинично звучат эти слова по отношению к больному человеку, но молодой официант стремится поскорее уйти с работы, у него есть оправдание, так как дома «жена в постели ждет», он не хочет работать допоздна из-за одного засидевшегося посетителя. Он сожалеет о так некстати вырвавшихся убийственных словах, «...не хотел быть несправедливым. Просто он очень спешил» [5, с. 282-283].

И Старик, и немолодой официант - одинокие люди, им просто некуда, да и незачем спешить, их никто не ждет. В отличие от них, у молодого сегодня все есть. «У тебя и молодость, и доверие, и работа есть, - сказал официант постарше. - Что еще человеку надо» [5, с. 283]. Без обиды, без зависти к молодому поколению, но с горечью произнесенные слова как нельзя лучше подтверждают безысходность поисков немолодых людей своего места в жизни.

Э. Хемингуэй не описывает стойкость Старика. Но героизм участников мировой войны проявлялся в том, что они старались выполнять свой долг. «Старик был очень стар, шел неуверенно, но с достоинством» [5, с. 282].

Внешняя черта, манера ходить, немногословность служат выявлению характера героя, потаенных свойств его души. Он устал от 
жизни, от одиночества, от окружающего мира, который он стремится покинуть:

- Зачем ему было на себя руки накладывать?

- Откуда я знаю.

- А как он это сделал?

- Повесился на веревке.

- Кто ж его из петли вынул?

- Племянница. [5, с. 281]

Фабула рассказа характерно хемингуэевская. Старик боролся против неблагоприятных обстоятельств, боролся мужественно, преодолевая боль и усталость, боролся отчаянно, до конца, но «мир ломает каждого, <..> тех, кто не хочет сломиться, он убивает» [5, c. 281]. Мы осознаем, что война уже успела искалечить Старика не только физически (он глух), но одновременно и духовно.

Безысходность, болезненное состояние души всего «потерянного поколения» сочетается с верой в «нормальную» жизнь без войны. Свет и достоинство - вот главные составляющие мирной жизни человека, исповедь человека, который выбрался из бездны и уцелел во время войны, но потерял смысл жизни в мирное время - характерная черта многих участников военных конфликтов XX века (афганский и чеченский конфликты).

Рассказ озаглавлен «Там, где чисто, светло». Определим это понятие, «чисто» значит «опрятно». Герои рассказа, Старик и немолодой официант кафе, по мнению окружающих - ненормальные люди. Один хотел повеситься, другой - жить без света и чистоты не может. Употребление понятия «чистота» в ином значении - качество, состояние. Смеем утверждать, что «чистота» для одного из героев, - это мучительный поиск истины большинства людей, тех, кто остался в живых, смысл их человеческого существования. «Не красота, а чистота спасет мир», утверждает наш современник, писатель Ф. Абрамов. «Разные мы люди, - сказал официант постарше. - Дело вовсе не только в молодости и доверии, хотя и то и другое чудесно... не хочется закрывать кафе потому, что кому-нибудь 
оно очень нужно... здесь чисто, опрятно... Свет яркий. Свет - это большое дело... Я из тех, кому ночью нужен свет» [5, с. 283].

В рассказе не упоминается напрямую война, но оба героя рассказа не находят своего места в мире, в жизни, мечтают о том, чтобы ночью всегда и всем было светло, и мы понимаем, что свет - это мир, там, где чисто, светло - это состояние без войны, «грязь» - не заклеенные крест-накрест окна, не проверка патрульными документов, «не грязь, не кровь». «...ручные гранаты, каски, винтовки - кое-где прикладом вверх, а штык воткнут в грязь» [5, с. 303], - таким увидел мир после атаки Николас Адамс, герой рассказа «Какими вы не будете».

Немолодой официант не воевал, но как подросток хорошо помнил все, что в детстве у него было связано с войной. Опираясь на собственные наблюдения и под влиянием суждений о войне, немолодой официант теряет веру не только в человека, но и в Бога. Равнодушие к Отцу всевышнему, его отрицание: «да придет ничто твое» - это своего рода богохульство, мы бы подчеркнули, что даже вера для него - это «суета сует и всяческая суета». Все в этом мире «ничто» [5, с. 303]. «Ничто - и оно ему так знакомо. Все - ничто, да и сам человек - ничто. Вот в чем дело, и ничего, кроме света, не надо, да еще чистоты и порядка. Некоторые живут и никогда этого не чувствуют, а он-то знает, что все это: nada у pues nada y nada у pues nada. Отче ничто, да святится ничто твое, да приидет ничто твое, да будет ничто твое, яко в ничто и в ничто. Nada y pues nada» [5, с. 303]. (Ничто и только ничто, ничто и только ничто - T.P.). Он осознал, что жизнь человека ничего не стоит, человек-победитель не получает ничего. Все - ничто - таков безнадежный вывод, к которому он приходит герой. Он впадает в отчаяние, «нарушает моральный кодекс: раз уж человек в этой жизни обречен на поражение, на смерть, то единственное, что ему остается, чтобы сохранить свое человеческое достоинство, это быть мужественным, не поддаваться обстоятельствам, какими бы страшными они ни были, соблюдать, как в спорте, правила «честной игры» [9, с. 8]. 
Образы рассказа художественно совершенны, мы как бы видим героев, слышим их голоса: «Он... остановился возле бара с блестящим титаном для кофе. Для вас? - спросил бармен. Nada Otro loco mas (Еще один полоумный. - перевод с исп. T.P.) «Свет яркий, приятный, а вот стойка не начищена», - сказал официант. «Время и пространство художественного произведения содержат в себе определенные «коды», расшифровка которых раскрывает нам авторское видение мира и места человека в нем, а также место данного текста в историко-литературном процессе», пишет Т. Литвин [11, с. 109]. «Код» света, чистоты, мира повсеместно вводится во все произведения писателя. В характере этих двух людей, Старика и немолодого официанта, есть много общего, объединяющего их при всех различиях облика и жизненного пути - и прежде всего - безысходность и разочарование, равнодушие к жизни вообще, и самое страшное - их одиночество.

В рассказе «На сон грядущий» герою рассказа, «когда меня оглушило взрывом и я почувствовал, как моя душа вырвалась и улетела от меня, а потом вернулась» [5, с. 268], было страшно оставаться в одиночестве. «За стенами дома ночь была полна обычных шумов прифронтовой полосы, но в темной комнате были соседи... Если можно было спать со светом, я не боялся уснуть, так как знал, что только в темноте моя душа может вырваться из тела...сознательно я никогда не решился бы заснуть в темноте» [5, с. 268]. То есть страх от пережитого на фронте или в прифронтовой полосе, боязнь спать без света будет преследовать героев произведений Э. Хэмингуэя на протяжении всей их жизни.

Необходимо указать на общую черту, присущую персонажам рассказов, - это дисгармония, одиночество в этом мире, «...мы убедились, что одной из главных его (Э. Хемингуэя. - T.P.) мыслей является мысль о нахождении человеческого достоинства» [9, c. 5]. «У стойки бара с достоинством не постоишь, а в такое время больше пойти некуда», - произносит немолодой официант. Монолог или диалог, являющийся одним из важнейших средств создания образа-персонажа, дает нам возможность проникнуть в его 
170 Наукові записки ХНПУ ім. Г.С. Сковороди. Літературознавство, 2019, вип. 3(93)

внутренний мир, глубже понять содержание рассказа. При этом писатель должен быть, прежде всего, внимательным наблюдателем жизни. «Даже если вы убиты горем, стоя у постели умирающего отца, вы должны замечать все, до последней мелочи, пусть даже это причиняет вам страдания».

Знаменитый хемингуэевский принцип айсберга рождался из наблюдения за деталями. Герои рассуждают о вине в рассказе «Рог быка», о пиве в рассказе «Вино Вайоминга», о водке в рассказе (агуардиенте - исп.), и только одно меткое слово, жест, голос указывают на трагедию.

Э. Хэмингуэй верил, что «только правдой можно помочь человеку», писатель должен писать правду, искать ее: «Писать правду о войне очень опасно, и очень опасно доискиваться правды... Когда человек едет на фронт искать правду, он может вместо нее найти смерть» [5, с. 7]. Не оставлял писатель поиски правды о войне в 1918, 1938, 1944 годах. В 1948 году Э. Хемингуэй приходит к выводу: «чем ближе к передовой, тем более замечательных людей там встречаешь; зато те, кто затевает, разжигает и ведет войну, - свиньи, думающие только об экономической конкуренции и о том, что на этом можно нажиться... все, кто наживается на войне, и кто способствует ее разжиганию, должны быть расстреляны в первый же день военных действий доверенными представителями честных граждан своей страны, которых они посылают сражаться» [6, с. 10].

В рассказе «Свет мира», в ожидании поезда происходит встреча героев событий (героя без имени и его сопровождающего по имени Томми) на станции железнодорожного вокзала, встреча с проститутками, «на станции сидели пять шлюх, они казались огромными, одна из них - пудов десять», шестеро белых мужчин и три индейца [5, с. 290]. В начале рассказа женщины не вызывают у героя никаких положительных эмоций, он с недоумением рассматривает их вызывающе яркие платья, видит в них лишь «слоновые туши», замечает «пергидрольную» блондинку, и все они для него, без исключения, - шлюхи. 
Женщины вспоминают мирное время, идеализируют его как «свет мира», в основе которого лежит их тоска и трагедия невостребованной любви, вспоминают одного из боксеров, Стива Кетчела из Кадильяка. «Он был самый сильный, самый лучший и самый красивый мужчина на свете», - говорит одна из них, хотя и не знала его близко. «Он был как бог, честное слово. Такой белый, и чистый, и гладкий, и красивый, и ловкий, и быстрый, как тигр или как молния», - продолжает со слезами другая, близкая ему женщина [5, c. 290]. У женщин из прежней, довоенной жизни, «остались воспоминания, мои чудные, живые воспоминания», и они, как и многие другие, в этой жизни живут воспоминаниями. «Она улыбнулась, и мне показалось, что я никогда не встречал женщины красивее. У нее было очень красивое лицо, и приятная гладкая кожа, и певучий голос, у нее был удивительно красивый голос» [5, с. 288], и «она была очень славная и приветливая. Но, господи, до чего же она была толста» [5, с. 292].

Э. Хэмингуэй писал: «Великие писатели обладают даром великолепной краткости». А.П. Чехов выразил мысль более лаконично - «краткость - сестра таланта». Отсюда - лаконизм языка Э. Хэмингуэя, передающийся красноречивым подтекстом, умение через детали показать главное. «Герои умалчивают о своих трудностях, и порою кажется, что чем тяжелее у них на душе, тем непринужденнее течет беззаботный диалог, - таковы «правила игры», - «однако равновесие текста и подтекста нигде не нарушается, и психологическая характеристика героев остается убедительной», - писал А. Старцев в послесловии «Молодой Хемингуэй и «потерянное поколение» [5, с. 711].

Вся группа людей на вокзале - это простые люди, безработные, травмированные войной, ищущие свое место в послевоенном мире (повар, лесоруб, индейцы, женщины и др.). Выстоять и найти свое место в жизни им помогают неиссякаемый юмор, смех, ирония, шутка, а порой и горький смех.

Интересна перекличка с рассказом Л. Андреева «Красный смех», который описывает события русско-японской войны. Слова 
«безумие и ужас» звучат в его произведении. «Безумный ужас войны с ее насилием над чувствами и разумом людей воплощен Андреевым не с помощью конкретных сцен сражений, смерти солдат, но с помощью предельно обобщенного, символического образа Красного (кровавого) смеха. «Это красный смех. Когда земля сходит с ума, она начинает так смеяться» [12, с. 58]. «Проезжая по дороге на велосипеде и временами соскакивая, когда полотно было слишком изрыто, Николас Адамс понял, что происходило здесь по тому, как лежали трупы. Они лежали поодиночке и вповалку, в высокой траве луга и вдоль дороги, над ними вились мухи, карманы у них были вывернуты, и вокруг каждого тела или группы тел были раскиданы бумаги», - так начинается правдивое описание после атаки в рассказе «Какими вы не будете», увиденного глазами главного участника событий Николаса Адамса [5, с 203].

Литературная критика положительно приняла сборник Э. Хемингуэя «В наше время» (1925). Это цикл новелл, «связанных сквозной, во многом автобиографичной фигурой юного Ника Адамса, начинающего писателя, вступающего в суровый и трагический мир» [3]. Ник Адамс был первым «героем кодекса» в хемингуэевском ряду. Через год этот образ появляется вновь, только теперь в лице Джейка Барнса из романа «И восходит солнце. Фиеста» (1926). «Но автобиографизм заключается не в совпадении деталей, а в сходстве духовного пути автора и очень впечатлительного Николаса Адамса, склонного к самоанализу и вместе с тем умеющего наблюдать жизнь и людей...Он пробовал запомнить все до последней черточки и держать все в строгом порядке...но вдруг, безо всякой причины, все спутывалось» [5, с. 310], и Ник впадал в спасительное забытье. Страх быть убитым или раненым, вынуждали принимать его «сто граммов» на фронте: «Я накачивался перед каждой атакой...Я этого ни капли не стыжусь Я никогда не видел вас пьяным. А в ту ночь, когда мы ехали из Местре в Портогранде, и я улегся спать, и укрылся велосипедом вместо одеяла, и все старался натянуть его до самого подбородка?» [5, с. 307]. Сны Николаса Адамса становятся средством преодоления мира: «Так где же он бывает каждую ночь, 
и в чем опасность, и почему он каждый раз просыпается весь в поту, испуганный больше, чем под любым обстрелом...» [5, с. 307].

Его преследует сон - наваждение, где «нет домов, но и города нет, он мучается вопросом, а был ли вообще дом, низкая конюшня и канал? Фронтовое его не пугало, и он никогда больше не видел фронта». [5, с. 310]. Спасительные сны героя отстраняли его от пережитого, заставляли забыть ужас любого обстрела, от сгущения и преувеличения фактов гибели товарищей. «Его взвод 1899 года рождения, только что прибывший на фронт, запсиховал во время артиллерийской подготовки...Если взвод не поднимется в атаку, расквасьте нос и тому сопляку и вытолкайте его коленкой под задницу. Как вы думаете, поднимутся они? Если нет, пристрелите двоих-троих» [5, с. 308]. Бессмыслицы войны, когда «с неподражаемым бесстрастием и законоблюстительским рвением людей, распоряжающихся чужой жизнью, в то время как их собственной ничто не угрожает» [6, с. 658].

Сочетание изображения внешнего облика и внутреннего, психологического своеобразия человека в полной мере раскрыто в образе Ника. Ему больно говорить о своих ранениях: «если вас интересуют шрамы, я могу показать вам очень интересные, но я предпочитаю поговорить о кузнечиках. То есть о том, что мы называем кузнечиками, а на самом деле это саранча» [5, с. 312]. И далее очень подробно Ник характеризует американский вид саранчи: «мы называли коричневая средняя, она меньше всех размокает в воде, и рыба лучше всего идет на нее...коричневые средние - это плотные, жирные, восхитительные кузнецы...» [5, с. 312]. Рассказом о саранче он словно стремился защитить свою раненую душу. Э. Хемингуэй погружается в исследование сложного духовного мира человека в раннем рассказе «На Биг-Ривер» (в книге рассказов «В наше время»), когда его одноименный герой Ник не увидел города Сеней, «весь он был стерт с лица земли, ничего не было, кроме рельсов и обгорелой земли, но река была на месте» [5, с. 124].

И снова наше внимание автор как бы уводит в сторону от проблемы, но акценты расставлены - города нет, а кузнечик остался: «это 
174 Наукові записки ХНПУ ім. Г.С. Сковороди. Літературознавство, 2019, вип. 3(93)

были кузнечики, черные, как сажа, оттого, что жили на обугленной земле. Он осторожно протянул руку и поймал кузнечика за крылья, затем подбросил кузнечика в воздух и проводил его взглядом, когда тот полетел через дорогу к обугленному пню» [5, с. 125]. У героя нет примиренности с жизнью, но есть какая-то мучительная тоска по гармонии, по идеалу. Повышенный интерес к внутреннему миру человека закономерно привел Э. Хемингуэя к подлинному психологизму.

Схожесть автора и его героев дала возможность писателю раскрыть не физические, а психологические страдания человека на войне. Выстоять Нику помогает «природа, выступая целительницей душевных ран, вечным источником радости...Река бурлила вокруг деревянных свай форели неподвижно висели в потоке» и т.д. «город Сеней сгорел, и склоны кругом обгорели и стали совсем другими, но это ничего. Всё не могло же сгореть. Ник был в этом уверен» [5, c. 126]. «Всё не могло же сгореть», зыбкость жизни звучит в рассказах Э. Хемингуэя. Природа «вечна, как герой». Глазами Николаса Адамса писатель сам смотрит на мир, без предрассудков. В повести «Старик и море» главный горой говорит: «человек не для того создан, чтобы терпеть поражения...Человека можно уничтожить, но его нельзя победить» [9, с. 12].

Таким образом, мы пришли к выводу, что персонажи новелл испанской тематики военных годов «Там, где чисто, светло» (об одиночестве старика), «Какими вы не будете» (о военных событиях), «Свет мира» (рассказ о проститутках, иронично и грустно вспоминающих прошлое) в целом отвергнуты успешным миром. Объективность восприятия и изображения реальности (через ее преломление в сознании основных действующих лиц), сосредоточенность на оттенках их чувств и настроений, сокращение дистанции между авторским сознанием и духовным настроем главных героев, предельная откровенность и неподдельность движений души, соединение нравов, истории, природы с хроникой одной человеческой судьбы - исключительно яркая творческая индивидуальность Э. Хемингуэя, описывающего ход истории и литературы. Перспективы 
дальнейших исследований могут быть связаны не только с испанской темой в творчестве писателя, но и с иной тематикой его рассказов.

\section{Литература}

1. Волкова Л.А. Функции портрета в литературном произведении (на материале романа Ф.М.Достоевского «Преступление и наказание»). Харьков: Фолио, 2016. 198 с.

2. Гиленсон Б. Видеть впереди вечность. Послесловие к сборнику прозы Хемингуэя. Панорама, 1993. 2006. URL: http: www.noblit.runode1077

3. Клевалина Н. Эрнест Хемингуэй: Победитель не получает ничего. Вокруг света, 2005. URL: http:www.vokrugsveta.ruvsarticle1104

4. Хемингуэй Э. Собрание сочинений: в 4 тт. М.: Худ. лит., 1968.

5. Хемингуэй Э. Собрание сочинений: в 4 тт. Т. 1. М.: Худ. лит., 1968. $719 \mathrm{c}$.

6. Хемингуэй Э. Собрание сочинений: в 4 тт. Т. 2. М.: Худ. лит., 1968. $679 \mathrm{c.}$

7. Хемингуэй Э. Собрание сочинений: в 4 тт. Т. 3. М.: Худ. лит., 1968. $750 \mathrm{c.}$

8. Хемингуэй Э. Собрание сочинений: в 4 тт. Т. 4. М.: Худ. лит., 1968. $558 \mathrm{c.}$

9. Х Хемингуэй Э. Библиотека классики. М.: Худ. лит., 1988. 557 с.

10. Лотман Ю.М. Портрет. Статьи по семиотике культуры и искусства. С.-Пб.: Академический проект, 2002. С. 349-375.

11. Литвин Т.В. Часо-просторові структури у контексті роману О.Хакслі «Новий дивний світ». Харків: Фоліо, 2016. 198 с.

12. Этова О.В. История русской литературы X-XX веков. Русская литература 2-ой половины ХІХ-ХХ вв. М.: Изд-во СГУ, 2001. 151 с.

\section{References}

1. Volkova L.A. Funktsii portreta $\mathrm{v}$ literaturnom proizvedenii (na materiale romana F.M. Dostoevskogo «Prestuplenie i nakazanie») [Functions of the portrait in a literary work (based on the material of the novel by F. M. Dostoevsky "Crime and Punishment")]. Kharkov: Folio, 2016. $198 \mathrm{~s}$.

2. Gilenson B. Videt vperedi vechnost [See ahead of eternity]. Posleslovie k sborniku prozy Khemingueya. Panorama, 1993. 2006. URL: http: www. noblit.runode 1077

3. Klevalina N. Ernest Kheminguey: Pobeditel ne poluchaet nichego [Ernest Hemingway: Winner Gets Nothing]. Vokrug sveta, 2005. URL: http:www. vokrugsveta.ruvsarticle1104 
176 Наукові записки ХНПУ ім. Г.С. Сковороди. Літературознавство, 2019, вип. 3(93)

4. Kheminguey E. Sobranie sochineniy v 4 tt. [Collected works in $4 \mathrm{tt}$ ]. Moskva: Khud. lit., 1968.

5. Kheminguey E. Sobranie sochineniy v 4 tt. [Collected works in $4 \mathrm{tt}$ ]. T. 1. Moskva: Khud. lit., 1968. - 719 s.

6. Kheminguey E. Sobranie sochineniy v 4 tt. [Collected works in 4 tt]. T. 2. Moskva: Khud. lit., 1968. - 679 s.

7. Kheminguey E. Sobranie sochineniy v 4 tt. [Collected works in 4 tt]. T. 3. Moskva: Khud. lit., 1968. - 750 s.

8. Kheminguey E. Sobranie sochineniy v 4 tt. [Collected works in 4 tt]. T. 4. Moskva: Khud. lit., 1968. - 558 s.

9. Kheminguey E. Biblioteka klassiki [Classic library]. Moskva: Khud. lit., 1988. $557 \mathrm{~s}$.

10. Lotman Yu.M. Portret. Stati po semiotike kultury i iskusstva [Portrait. Articles on semiotics of culture and art] Sankt-Peterburg: Akademicheskiy proekt, 2002. S. 349-375.

11. Lytvyn T.V. Chaso-prostorovi struktury u konteksti romanu O.Khaksli «Novyi dyvnyi svit» [Time-space structures in the context of O. Huxley's novel A New Wonderful World]. Kharkiv: Folio, 2016. 198 s.

12. Etova O.V. Istoriya russkoy literatury $\mathrm{X}-\mathrm{XX}$ vekov. Russkaya literatura 2-oy poloviny XIX-XX vv. [History of Russian literature of the X-XX centuries]. Moskva: Izd-vo SGU, 2001. $151 \mathrm{~s}$.

\section{Анотація}

\section{Т. Разуменко. Іспанська тема в оповіданнях Е. Хемінгуея «Переможець не одержус нічого»}

Ернест Хемінгуей - знакова фігура в літературі XX століття, його ім'я і творчість назавжди увійшли в історію світової літератури. Метою статті $€$ характеристика способу розкриття внутрішнього світу і емоційного стану героїв, психологізм «втраченого покоління» у взаємодії зовнішнього і внутрішнього його прояву через громадянську війну в Іспанії. У статті аналізуються розповіді «Там, де чисто, світло», «Якими ви не будете», «Світло життя».

Вогняна атмосфера «кривавого десятиліття» внесла нові теми в творчість письменника, Іспанія стала для нього «моментом істини», він відчуває невідворотність майбутньої світової війни. В Іспанії Е. Хемінгуей в повній мірі проявив себе і як художник, і як громадянин. Всі герої його оповідань - це прості люди, чоловіки і жінки, безробітні, травмовані війною, які шукають своє місце в післявоєнному світі (кухар, лісоруб, індіанці, повії та ін.). Вистояти і знайти своє місце в житті їм допомагають невичерпний гумор, сміх, самоіронія, жарт, а часом і гіркий сміх. 
«Код» світла, чистоти, миру усюди включається в твори письменника. В характері його персонажів є багато спільного, що об'єднує їх при всіх відмінностях зовнішності й життєвого шляху - і перш за все, - безвихідь і розчарування, байдужість до життя взагалі, і найстрашніше - їхня самотність. Гранична відвертість і справжність рухів душі, з'єднання моралі, історії, природи з хронікою однієї людської долі, - виключно яскрава творча індивідуальність Е. Хемінгуея, який описує своїх героїв.

У роботі ми дійшли висновку, що персонажі новел про воєнні роки в Іспанії «Там, де чисто, світло» (про самотнього старого), «Якими ви не будете» (про війну), «Світло життя» (сумно-іронічна розповідь про повій, які згадали минуле) так чи інакше відторгнуті благополучним суспільством. Безвихідь, болісний стан душі всього «втраченого покоління» поєднується 3 вірою в «нормальне» життя без війни персонажів його оповідань. Світло і гідність - ось головні складові мирного життя людини, сповідь людини, яка вибралася зі безодні й вціліла під час війни, але втратила сенс життя в мирний час, - характерна риса багатьох постатей військових конфліктів.

Ключові слова: іспанська тема, Е. Хемінгуей, «Переможець не одержує нічого», «втрачене покоління», «код» світла.

\section{Аннотация \\ Т. Разуменко. Испанская тема в рассказах Э. Хемингуэя «Победитель не получает ничего»}

Эрнест Хемингуэй - знаковая фигура в литературе XX столетия, его имя и творчество навсегда вошли в историю мировой литературы. Целью статьи является характеристика способа раскрытия внутреннего мира и эмоционального состояния героев, психологизм «потерянного поколения» во взаимодействии внешнего и внутреннего его проявления через гражданскую войну в Испании. В статье анализируются рассказы «Там, где чисто, светло», «Какими вы не будете», «Свет мира».

Накаленная атмосфера «кровавого десятилетия» внесла новые темы в творчество писателя, Испания стала для него «моментом истины», он чувствует неотвратимость грядущей мировой войны. В Испании Э. Хемингуэй в полной мере выразил себя и как художник, и как гражданин. Все герои его рассказов - это простые люди, мужчины и женщины, безработные, травмированные войной, ищущие свое место в послевоенном мире (повар, лесоруб, индейцы, проститутки и др.). Выстоять и найти свое место в жизни им помогают неиссякаемый юмор, смех, самоирония, шутка, а порой и горький смех.

«Код» света, чистоты, мира повсеместно вводится во все произведения писателя. В характере его персонажей есть много общего, объединяющего 
их при всех различиях облика и жизненного пути - и прежде всего, - безысходность и разочарование, равнодушие к жизни вообще, и самое страшное - их одиночество. Предельная откровенность и неподдельность движений души, соединение нравов, истории, природы с хроникой одной человеческой судьбы, - исключительно яркая творческая индивидуальность Э. Хемингуэя, описывающего своих героев.

В работе мы пришли к выводу, что персонажи новелл о военных годах в Испании «Там, где чисто, светло» (об одиноком старике), «Какими вы не будете» (о войне), «Свет мира» (грустно-ироничный рассказ о проститутках, вспомнивших прошлое) так или иначе отторгнуты благополучным обществом. Безысходность, болезненное состояние души всего «потерянного поколения» сочетается с верой в «нормальную» жизнь без войны персонажей его рассказов. Свет и достоинство - вот главные составляющие мирной жизни человека, исповедь человека, который выбрался из бездны и уцелел во время войны, но потерял смысл жизни в мирное время, - характерная черта многих персонажей военных конфликтов.

Ключевые слова: испанская тема, Э. Хемингуэй, «Победитель не получает ничего», «потерянное поколение», «код» света.

\section{Summary}

\section{T. Razumenko. Spanish Theme in E. Hemingway's Stories 'The Winner Gets Nothing'}

Ernest Hemingway is a symbolic figure in the literature of the 20th century. His name and works entered the history of world literature forever. The purpose of the article is to characterize the way of opening the inner world and the emotional state of the characters, the psychology of the 'lost generation' in the interaction of its external and internal manifestations through the civil war in Spain. The article analyzes the stories 'A clean, well-lighted place', 'A way you'll never be', 'The light of the world'.

The heated atmosphere of the 'bloody decade' introduced new themes into the writer's work. Spain became a 'moment of truth' for E. Hemingway. He feels the inevitability of the coming world war. E. Hemingway expressed himself in Spain completely as an artist, and as a citizen. All the characters of his stories are simple people, men and women, unemployed, traumatized by war, looking for their place in the post-war world (a cook, a lumberjack, Indians, prostitutes etc.). Endless humor, laughter, self-irony, joke, and sometimes bitter laughter help them to stand and find their place in life.

The 'code' of light, purity, and peace are universally introduced into all writer's works. In the personality of his characters there is much in common, unifying them with all the differences in appearance and life path, and above all, 
hopelessness and disappointment, indifference to life in general, and the most terrible is their loneliness. The utmost frankness and genuineness of soul movements, the combination of morals, history, nature with the chronicle of only human destiny, are exceptionally bright creative personalities of E. Hemingway, who describes his characters.

In our work we came to the conclusion that the characters of the stories about the war years in Spain 'A clean, well-lighted place' (about a lonely old man), 'A way you'll never be' (about the war), 'The light of the world' (the sad and ironic story about prostitutes who remembered the past) anyway are rejected by a prosperous society. Hopelessness, dark state of the soul of 'lost generation' are combined with the belief in the 'ordinary' life without the war for the characters of E. Hemingway's stories. Light and dignity are the main components of a person's peaceful life, the confession of a person who got out of the abyss and survived during the war, but who lost the sense of life in peacetime, they are distinguishing features of many characters in military conflicts.

Keywords: Spanish theme, E. Hemingway, 'The Winner Gets Nothing', 'lost generation', 'code' of light.

\section{Інформація про автора}

Разуменко Тетяна Олегівна - кандидат філологічних наук, доцент кафедри англійської філології Харківського національного педагогічного університету імені Г.С. Сковороди; вул. Валентинівська, 2, м. Харків, 61168, Україна; e-mail: razumenkot@gmail.com; http://orcid.org/0000-00020682-3812 